\title{
The Effectiveness of Training on Improving the Ability of Health Cadres in Early Detection of Stunting in Toddlers
}

\author{
Rina Tampake ${ }^{1 *}$, Ros Arianty ${ }^{2}$, Selvi A. Mangundap ${ }^{1}$, Baiq Emy ${ }^{1}$, Hanum Sasmita $^{2}$ \\ ${ }^{1}$ Department of Nursing, Poltekkes Kemenkes Palu, Palu, Indonesia; ${ }^{2}$ Department of Sanitation, Poltekkes Kemenkes Palu, \\ Palu, Indonesia
}

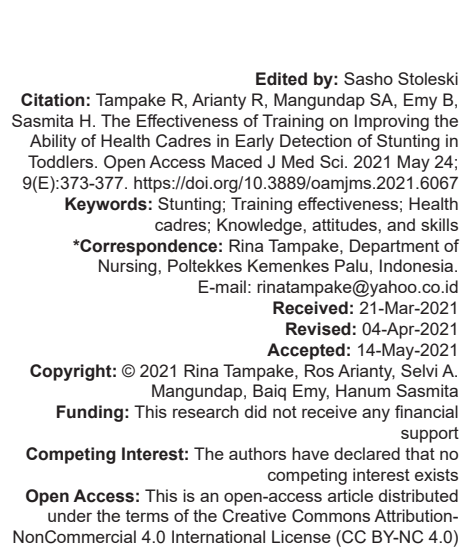

NonCommercial 40 of the Creative Commons Attribution-

\begin{abstract}
AIM: This study aimed to determine the effectiveness of training in improving health cadres' ability in early detection and risk factors of stunting in toddlers.

METHODS: The research method used was a quasi-experimental non-randomized pre- and post-test only contro design. The independent variable was cadre training. The training was conducted through learning activities on health cadres using lecture method, question and answer method, and brainstorming accompanied by training booklets/modules and demonstrations. The dependent variable was knowledge, attitudes, and skills in detecting stunting and risk factors for stunting in children under-five. There were 53 health cadres as samples scattered in the Tomini Community Health Center with the purposive sampling technique. The data analysis technique used was a parametric statistical paired sample t-test.

RESULTS: Training of health cadres effectively increased health cadres' ability to detect stunting and risk factors for stunting in children under-five. The different test results for each variable that showed the pre-post-test $p$-value for knowledge, attitudes, and health cadres' skills were 0.000 , smaller than the significance level of $0.05(p<0.05)$. Besides, the mean score of each variable obtained after training for health cadres was more significant than before training, including knowledge $17.392>12.264$, attitudes $33.603>27.226$, and skills $90.019>62113$. Those are means that cadres' training effectively increased the knowledge, attitudes, and skills of health cadres in detecting stunting and risk factors for stunting in children under-five.
\end{abstract}

CONCLUSION: Training of health cadres effectively increases the knowledge, attitudes, and skills of health cadres about early detection and risk factors of stunting in the working area of Tomini Public Health Centre, Parigi Moutong Regency.

\section{Introduction}

The prevalence of stunting of children underfive in Indonesia is the third country with the highest prevalence in the Southeast Asia/Southeast Asia Regional. The average prevalence of stunting underfive in Indonesia in 2005-2017 was 36.4\% [1]. The incidence of short toddlers or commonly referred to as stunting, is one of the nutritional problems experienced by toddlers in the world today. In $2017,22.2 \%$ or around 150.8 million children under-five in the world were stunted. However, this figure has decreased compared to the stunting rate in $2000,32.6 \%$ [2].

One of the efforts to create a healthy Indonesian society is by empowering the community or cadres willing to voluntarily get involved in integrated health service post (posyandu) issues. Health cadres are one of the community groups that can be empowered in detecting stunting early. Cadre training to increase the ability to perform early detection of stunting and risk factors in toddlers is needed. Education is health promotion to convey health messages to the community, groups, or individuals to hope that the community, group, or individual can learn better health. In the end, this knowledge is expected to influence behavior. The existence of this promotion is expected to bring about changes in behavior [3], [4], [5].

One of the elements determining increasing cadres' knowledge and skills is learning methods through education [6]. Potential health cadres can improve health status to support development goals and provide services. They can also help individuals and communities adopt healthy lifestyle behaviors [7]. Health cadres play an essential role as the front guard in providing services to the community through Posyandu and outside the Posyandu. However, many cadres do not yet have adequate understanding and skills in carrying out their duties. Posyandu cadres should be able to manage both the Posyandu and outside Posyandu activities properly. Those are due to their understand well the conditions of the needs of their community. Health cadres are people who are chosen, willing, capable, and have the time and concern for basic social services for the community. Therefore, Posyandu cadres' training is an effort to increase health cadres' capacity and capability [8], [9].

This study aimed to determine cadre training's effectiveness in increasing health cadres' ability in early 
detection and risk factors of stunting in toddlers in the Tomini Public Health Center, Parigi Moutong District, Central Sulawesi Province.

\section{Methods}

This type of research was quantitative research. The research design used was a quasi-experimental non-randomized pre- and post-test only control design. In this study, before giving the treatment, the initial data was collected then given treatment, namely cadre training, then the final data was collected (Figure 1).

This study's population was all cadres in 28 integrated health service posts (Posyandu) in the Tomini Public Health Center (Puskesmas) working area, 140 people. The sampling technique taken in this study was based on non-probability sampling with the purposive sampling technique. The criteria were as follows: (1) Two cadres of delegates from each integrated health service post (Posyandu), (2) never attended a cadre training on stunting, (3) willing to be a respondent, (4) present during the research, and (5) completely attended the training conducted. The total samples used in this study were about 58 cadres.

\section{Data collection}

Data collection on knowledge, attitudes, and skills for early detection of stunting and risk factors for stunting was carried out before the cadre training intervention. Intervention using booklets or modules. Data collection on the level of knowledge, attitudes, and skills was carried out after training interventions for health cadres on early detection of stunting and risk factors for stunting.

The nonparametric statistical test used in nominal data is the paired sample difference test using the McNemar test. The independent sample difference test used the Chi-square test.

\section{Results}

The description of the respondents' characteristics showed that most of the health cadres

Table 1: Characteristics of respondents

\begin{tabular}{lll}
\hline Characteristics & $\mathrm{n}=53$ & $\%$ \\
\hline Age & & \\
$<25$ years & 11 & 20.8 \\
$25-34$ years & 18 & 34.0 \\
$35-44$ years & 20 & 37.7 \\
$\quad \geq 45$ years & 4 & 7.5 \\
Level of education & & \\
Elementary school & 9 & 17 \\
Junior high school & 18 & 33.9 \\
Senior high school & 26 & 49.1 \\
\hline
\end{tabular}

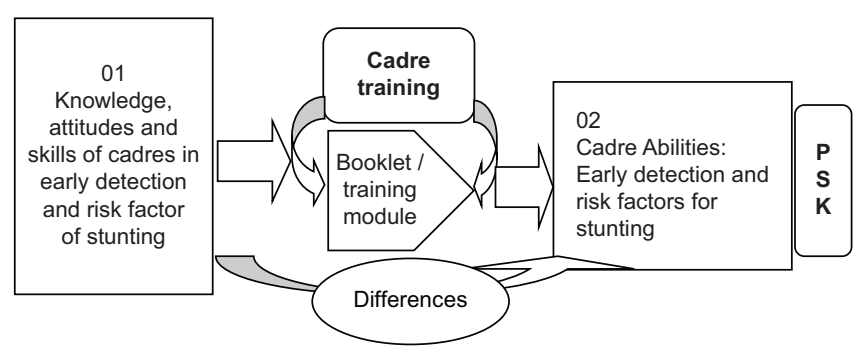

Figure 1: 01 (initial data collection of knowledge, attitudes, and skills, early detection of stunting and risk factors), intervention (training for cadres); 02 (retrieval of final data on knowledge, attitudes, and skills of cadres for early detection of stunting and risk factors)

aged 35-44 years (37.7\%) and the lowest were aged $\geq 45$ years $(7.5 \%)$. The education level of respondents mainly was high school (SMA/SMK) level (49.1\%), and the lowest was elementary school graduates (17\%) (Table 1).

Figure 2 shows the situation before training (pretest). Health cadres' knowledge about early detection of stunting and risk factors for stunting in under-5 children was categorized as only $52.8 \%$, categorized as sufficient knowledge. About $5.7 \%$ of cadres categorized poor knowledge. However, after training on early detection and risk factors of stunting in toddlers, there was an increase every week until the end of the $3^{\text {rd }}$ week (posttest). At the end of the post-test week, 53 health cadres $(100 \%)$ were included in the good category.

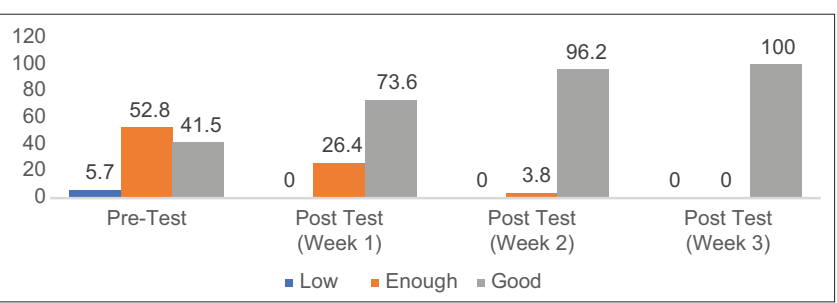

Figure 2: The distribution of health cadres' knowledge level (pre-test and post-test)

Figure 3 shows an increase in the distribution of health cadres' attitudes in the "good category" every week. Before the training of health cadres (pre-test), the attitude of health cadres about early detection and risk factors of stunting in the under-5 majority were "adequate" category $(60.4 \%)$. The $7.5 \%$ of health cadres were still in the "poor" category. However, after being given training, health cadres' attitude every week seemed improved. At the end of the post-test week (Week III), 53 health cadres $(100 \%)$, health cadres' attitudes about early detection of stunting, and risk factors for stunting in toddlers were included in the good category.

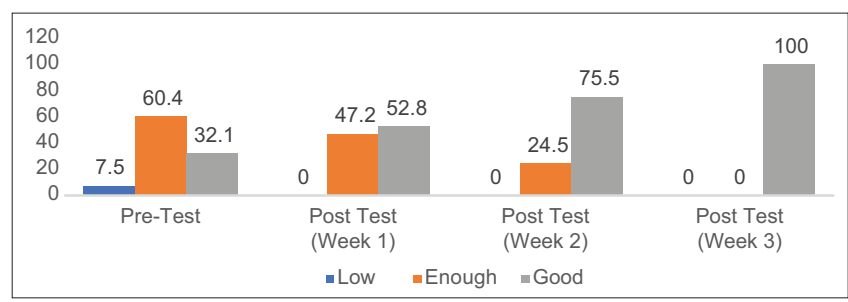

Figure 3: The distribution of health cadres' attitudes (pre-test and post-test) 


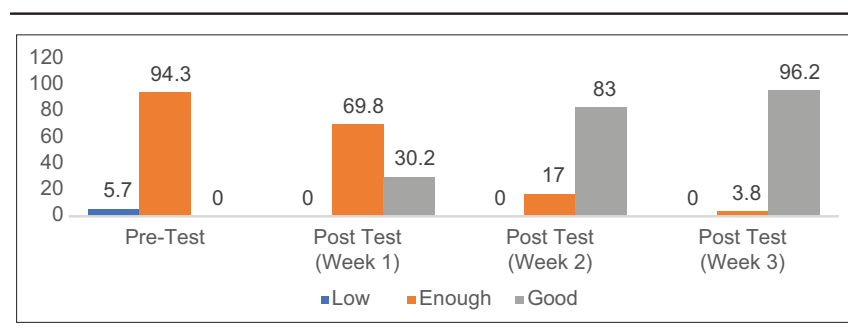

Figure 4: The skills of health cadres' (pre-test and post-test)

Figure 4 shows an increase towards the "good" category every week (Figure 4). Before the training (pretest), the skills of health cadres' attitudes about early detection of stunting and risk factors for stunting in underfive were mainly in the "adequate" category, about $94.3 \%$. The remaining $5.7 \%$ cadres were categorized "less." However, after training early detection of stunting and risk factors for stunting in toddlers, health cadres' skills showed a better change every week. At the end of the post-test week (Week III), the skills of 53 health cadres (100\%) about early detection of stunting and risk factors for stunting in children under-five were included in the good category.

Table 2 shows that the knowledge variable before the cadre training intervention (pre-test) was lower than after being given service (post-test) with a mean difference of 5.132. Besides, the t-count value of 14.318 with a significance value $(p)=0.000$ was smaller with a significance level of $5 \%(0.000<0.05)$. It shows that the knowledge of health cadres before and after training health cadres about early detection of stunting and risk factors for stunting was significantly different.

Table 2: Results of paired sample t-test analysis

\begin{tabular}{llllll}
\hline Variable & Measurement & Mean & Std. deviation & Mean difference & p-value \\
\hline Knowledge & Pre-test & 12.264 & 2.346 & 5.132 & 0.000 \\
& Post-test & 17.392 & 1.915 & & \\
Attitude & Pre-test & 27.226 & 3.593 & 6.377 & 0.000 \\
& Post-test & 33.603 & 2.741 & & \\
Skills & Pre-test & 62.113 & 3.011 & 27.906 & 0.000 \\
\hline
\end{tabular}

Table 2 shows that in the attitude variable, the mean value of health cadres' attitudes before the cadre training intervention (pre-test) was lower than after being provided with service (post-test). The mean difference was 6.377 . The results showed the t-value of 13,573 with a significance value $(p)=0.000, p<0.05$. It means that health cadres' attitudes before and after training of health cadres on early detection of stunting and risk factors for stunting were significantly different. Table 2 shows the average value of health cadres' skills regarding early detection of stunting and risk factors for stunting before the cadre training intervention (pre-test) was lower than after being given service (post-test). The mean difference was 6.377 , and the t-value was 13.573 with a significance value $(p)=0.000$. It shows that the significance value $(p)$ was smaller with a significance level of $5 \%(0.000<0.05)$. It means that health cadres' attitudes before and after training of health cadres on early detection of stunting and risk factors for stunting were significantly different.

Table 3 shows a significant difference in knowledge from before being given training for health
Table 3: Comparison of the results of the knowledge variable t-test analysis

\begin{tabular}{llll}
\hline Variable & Measurement & Mean difference & p-value \\
\hline Pretest-Posttest week 1 & $\begin{array}{l}\text { Pre-test } \\
\text { Post-test week 1 }\end{array}$ & 2.151 & 0.000 \\
Post-test week 1-post-test week 2 & $\begin{array}{l}\text { Post-test week 1 } \\
\text { Post-test week 2 }\end{array}$ & 1.830 & 0.000 \\
Post-test week 2-post-test week 3 & $\begin{array}{l}\text { Post-test week 2 } \\
\text { Post-test week 3 }\end{array}$ & 1.151 & 0.000 \\
\hline
\end{tabular}

Table 4: Comparison of the results of the t-test analysis for attitude variables

\begin{tabular}{llll}
\hline Variable & Measurement & Mean difference & p-value \\
\hline Pretest-posttest week 1 & $\begin{array}{l}\text { Pre-test } \\
\text { Post-test week 1 }\end{array}$ & 2.509 & 0.000 \\
Post-test week 1-post-test week 2 & $\begin{array}{l}\text { Post-test week 1 } \\
\text { Post-test week 2 }\end{array}$ & 1.717 & 0.000 \\
Post-test week 2-post-test week 3 & $\begin{array}{l}\text { Post-test week 2 } \\
\text { Post-test week 3 }\end{array}$ & 2.151 & 0.000 \\
\hline
\end{tabular}

cadres after training at the end of the week. Table 4 shows a significant difference in attitudes from before being given training for health cadres to after being given training at the end of the week. It can be seen from the results of the significance value $(p)$ at the pre-test and week 1 , week 1 and week 2 , and week 2 and week 3 (post-test) which were smaller than the significance level of $5 \%(p<0.05)$. It means that training health cadres effectively improved health cadres' attitudes about early detection of stunting and risk factors.

Table 5 shows a significant difference in skills from before being given training for health cadres to after being given training at the end of the week. It can be seen from the results of the significance value $(p)$ at the pre-test and week 1 , week 1 and week 2 , and week 2 and week 3 (post-test) which were smaller than the significance level of $5 \%(p<0.05)$. It means that training health cadres effectively improved health cadres' skills in detecting stunting and risk factors.

Table 5: Comparison of the results of the t-test analysis for skills variables

\begin{tabular}{llll}
\hline Variable & Measurement & Mean difference & p-value \\
\hline Pretest-post-test week 1 & Pretest & 19.528 & 0.000 \\
Post-test week 1-post-test week 2 & $\begin{array}{l}\text { Post-test week 1 } \\
\text { Post-test week 1 }\end{array}$ & 4.019 & 0.000 \\
Post-test week 2 & $\begin{array}{l}\text { Post-test week 2 } \\
\text { Post-test week 2-post-test week w } 3\end{array}$ & 4.358 & 0.000 \\
\hline
\end{tabular}

\section{Discussion}

Stunting is a physical growth in height that is not normal according to age. Toddlers who are stunted exhibit chronically ill health, which can be dangerous if left untreated. One of the efforts that can be made to prevent the growth of stunting is through health cadres who are scattered throughout Indonesia. Several studies have shown that empowering communities or cadres who are willing to be involved in voluntary 
integrated health service posts (Posyandu) can reduce the risk of stunting in children under five [10], [11].

One form of an effort to improve health cadres' ability in early detection of stunting and risk factors for children under-five can be done by training health cadres. It is in line with the results of Yuliani et al., regarding the training of health cadres for early detection of stunting in toddlers in Betting Village. The results showed that increasing understanding of health cadres about early detection of stunting could be done through counseling and training [12]. Other research results show that after training, Posyandu cadres can understand the early detection of stunting. In addition, research shows that posyandu cadres have a vital role in informing them of optimal nutrition in preventing stunting and identifying risk factors for stunting in the Posyandu working area [13].

The results showed a change in the knowledge, attitudes, and skills of health cadres in early detection of stunting and risk factors for stunting in children under-five. The knowledge of health cadres in this study is the cadres' understanding of early detection of stunting and risk factors for stunting in children underfive, attitudes related to the response of health cadres about early detection of stunting, and risk factors for stunting in toddlers. In contrast, skills are related to cadres' ability to measure height/age in toddlers. This research is in line with the results, which show an increase in the health cadres' knowledge; before the activity was, $61.3 \%$ cadres had good knowledge and after activity increased to $93.5 \%$ [14]. It is in line with the results of the activities that have been carried out. It is seen that the training carried out has increased the knowledge of Family Welfare Movement (PKK) cadres trained in the good category by $54.5 \%$. It is following the predetermined success indicators. The training that was carried out effectively increased the knowledge and skills of PKK cadres in taking anthropometric measurements [15].

Furthermore, the t-test on health cadres' knowledge, attitudes, and skills regarding early detection of stunting and risk factors for stunting in children under-five showed a smaller $p$-value than $p<0.05$. It means that before and after training health cadres on early detection of stunting and risk factors for stunting in toddlers in the Tomini Public Health Center, Parigi Moutong Regency in 2020 was significantly different. Besides, each variable's mean value every week has increased. They indicated that cadre training provides a positive change in health cadres' ability to detect stunting and risk factors for stunting in toddlers. It shows that cadre training effectively increases health cadres' ability to detect stunting and risk factors for stunting in children under-five in the working area of Tomini Public Health Center, Parigi Moutong Regency, Central Sulawesi Province. This study's results are in line with research about the influence of health promotion on knowledge and attitudes with preventive measures of stunting by Posyandu cadres. They found $p<0.05$ and no significant effect on the control group with $p>0.05$ [5]. Another study also stated that the average intervention of knowledge, attitudes, and nutrition practices of cadres in the intervention group increased, especially in cadres nutrition management, increased by 7 points [16]. The assistance results showed that the ability and skills of early detection of the risk of stunting in health cadres increased from $35 \%$ to $88 \%$ [17].

\section{Conclusion}

Training of health cadres effectively increases the knowledge, attitudes, and skills of health cadres about early detection of stunting and risk factors for stunting in the working area of Tomini Public Health Centre, Parigi Moutong Regency.

\section{References}

1. Kemenkes RI. Laporan Nasional Riskesdas 2018. Jakarta: Badan Penelitian dan Pengembangan Kesehatan; 2018

2. Ri KK. Buletin Jendela Data dan Informasi Kesehatan, Bakt Husada Jakarta; 2018.

3. Notoatmodjo S. Promosi Kesehatan dan Perilaku Kesehatan. Jakarta: Rineka Cipta; 2012

4. Nurmala I. Promosi Kesehatan. Indonesia: Airlangga University Press; 2020.

5. Sewa R, Tumurang M, Boky $H$. The effect of health promotion on knowledge and attitudes with stunting prevention measures by posyandu cadres in the work area of the Bailang Community Health Center, Manado City. J KESMAS. 2019;8(4):80-8. https:// doi.org/10.36565/jab.v9i1.149

6. Triyanti M, Widagdo L, Syamsulhuda BM. Knowledge and skills improvement strategy cadre in monitoring growth toddler in Posyandu through training of volunteers with problem based learning method (BBM) and metode mind mapping (MM). J Prom Kesehatan Indones. 2017;12(2):265-77. https://doi.org/10.14710/ jpki.12.2.265-277. https://doi.org/10.14710/jpki.12.2.265-277

7. Susanto F, Claramita M, Handayani S. Peran kader posyandu dalam pemberdayaan masyarakat Bintan. Berita Kedokteran Masyarakat. 2017;33(1):13-8. https://doi.org/10.22146/ bkm.11911

8. Kemenkes RI. Kurikulum dan Modul Pelatihan Fasilitator Pemberdayaan Kader Posyandu. Direktorat Promosi Kesehatan; 2012.

9. Astutik RY, Palupi M. Modul Pelatihan Program KUWAT: Pada Wanita Menopause Oleh Kader Posyandu. Malaysia: Pustaka Abadi; 2019. https://doi.org/10.31983/link.v15i2.5155

10. De Onis M, Branca F. Childhood stunting: A global perspective. Matern Child Nutr. 2016;12:12-26. https://doi.org/10.1111/ mcn. 12231

11. Prendergast AJ, Humphrey JH. The stunting syndrome in developing countries. Paediatr Int Child Health. 
2014;34(4):250-65.

PMid:25310000

12. Yuliani E, Immawanti I, Yunding J, Irfan I, Haerianti M, Nurpadila $\mathrm{N}$. Health cadre training about early detection of stunting toddler in betteng village. J Pengabdian Masyarakat Kesehatan. 2018;4(2):41-6. https://doi.org/10.33023/jpm.v4i2.158

13. Megawati G, Wiramihardja S. Increase the capacity of Posyandu cadres in detecting and preventing stunting. Dharmakarya. 2019;8(3):154-9. https://doi.org/10.24198/dharmakarya. v8i3.20726

14. Adistie F, Lumbantobing VB, Maryam NN. Empowerment of health cadres in early detection of stunting and stimulation of growth and development in toddlers. Med Karya Kesehatan. 2018;1(2):173-84. https://doi.org/10.24198/mkk.v1i2.18863

15. Kesumasari C, Kurniati $Y$, Syam A, Salam A, Virani D. Pencegahan stunting melalui pemberdayaan kader PKK kecamatan barebbo di kabupaten bone. Panrita Abdi J
Pengabdian Pada Masyarakat. 2020;4(3):322-7. https://doi. org/10.20956/pa.v4i3.8083

16. Nikmawati EE, Kusharto CM, Khomsan A, Sukandar D, Atmawikarta A. Nutrition education interventions for mothers of toddlers and posyandu cadres to increase knowledge of attitudes and skills as well as nutritional status of toddlers. Invotec. 2009;5(15):50-55. Available from: $\quad$ http://www.jurnal.upi.edu/invotec/view/280/ intervensipendidikangizib agiibubalit adankaderpo syanduuntu kpeningkatanpsk(pengetahuansikapdanketerampilan) sertastatusgizibalita. [Last accessed on 2021 Mar 11]. https:// doi.org/10.25182/jgp.2009.4.3.140-150

17. Wuriningsih AY, Sari DW, Khasanah NN, Distinarista $H$, Rahayu T, Wahyuni S. Optimization of stunting prevention through self-help group-based stunting risk alert companion groups (KP-Scoring). J Community Engagem Health. 2021;4(1):58-65. https://doi.org/10.30994/jceh.v4i1.115 